\title{
Adolescence Online Religious Content Consumption and Their Tendency Toward Violent Extremism
}

\author{
Cahyo Setiadi Ramadhan ${ }^{1, *}$ Twediana Budi Hapsari ${ }^{2}$
}

\author{
${ }^{1,2}$ Department of Islamic Communication and Broadcasting, Faculty of Islamic Studies, Universitas Muhammadiyah \\ Yogyakarta, Indonesia \\ *Corresponding author.Email: cahyosetiadi@umy.ac.id
}

\begin{abstract}
Teenagers are at risk of engaging in dangerous behavior and accessing information from cyberspace. At the same time, extreme violent groups carry out propaganda on the internet. This study aims to examine the relationship between online religious learning and a person's tendency to violent extremism. This research is correlational quantitative research. Respondents are teenagers from five regions in Indonesia $(\mathrm{N}=750)$ aged between 13-18 years old. Measurements of online religious learning behavior scores and violent extremism tendencies were measured using a scale. The scores of the two scales were tested using the Rho correlation test because they did not meet the requirements to be tested using parametric statistical tests. The test results show that there is no correlation between online religious learning behavior and the tendency of violent extremism $(\mathrm{Rho}=0.017 ; \mathrm{p}=$ 0.638). Additional analysis using ANOVA indicates social and educational factors play a role in the individual's process of becoming prone to violent extremism.
\end{abstract}

Keywords: violent extremism, social media, religiosity

\section{INTRODUCTION}

Indonesia is currently experiencing a demographic bonus. The productive age population (aged 15-64 years) in Indonesia in 2020 has reached $70.72 \%$ of the total population of Indonesia [1]. The demographic bonus occurs because the productive age population can bear the burden of the unproductive age population so that they can develop their lives. In other words, to get the demographic bonus, it is necessary to take active steps and not just wait for an increase in the number of productive age population [2, 3, \& 4]. The Coordinating Minister for Human Development and Culture (Menko PMK) [5] and the Minister of Manpower [6] also mentioned the need for active steps to make this demographic bonus beneficial.

Including groups that need attention, namely the youth group. Adolescents according to the World Health Organization include individuals aged 10-19 years [7, 8]. Based on BPS data [1], the number of teenagers entering the production age is about $12.10 \%$ of the total population of productive age. To encourage Indonesia to benefit from the demographic bonus, we need to pay attention to these teenagers. During adolescence, the tendency to engage in risky behavior increases [9, 10, 11]. Among these risky behaviors include aggressive or violent behavior. This risky behavior can be an obstacle or deviate teenagers from activities that support their future. Many factors lead to risky behavior in adolescents. In the study found a correlation between the behavior of accessing social media with involvement in risky behavior [12].
This relationship needs attention. Teenagers today are individuals born between 2001-2010. This generation is a part of Generation Z i.e. individuals born araound 1997-2021[13, 14]. They often use and are familiar with various kinds of social media $[15,16]$. Their perception of the virtual world makes them use social media as a place to find or check information. They do this easily [17]. These conditions can make them more susceptible to various risky or dangerous behaviors. On the other hand, extreme groups that tend to behave violently spread various materials about violence and extreme behavior in social media $[18,19,20]$. The tendency of teenagers to access new media and the dissemination of violent extremism material raises the risk of teenagers being exposed to even joining violent extremist groups.

This concern arises for there are several studies show the empathy of the Indonesian Muslim middle class towards violent radicalism movements. The results of a survey conducted on university students and high school students in 2007 showed that $9.5 \%$ of respondents tended to be intolerant of non-Muslim minorities and $65 \%$ of them expressed support for sweeping actions carried out in several places [21]. On the other hand, the tendency of teenagers on the internet, causes them to tend to independently study Islam or in popular terms 'recitation' through online media such as YouTube, Instagram, or through other online media [21, 22, 23, 24]. Currently social media is an important factor for millennial youth to study religion, in addition to family, school and religious social organizations. Millennial teenagers get religious knowledge from the interaction of various learning sources, groups and environments both online and offline. Learning 
religion through 'viral' clerics is a common phenomenon among millennial teenagers today. If in the past a cleric was known through the tabligh akbar or often appeared on television, now the clerics who have accounts on social media are better known to the millennials, including Ustad Abdul Somad, Ustad Hanan Attaki and Ustad Felix Siaw. The conclusion of this study is that today's millennial youths that they gain more religious knowledge through cyberspace which has also affected their lives [21, 22, 23, 24].

For this reason, the spread of violent and extreme material through cyberspace needs to be prevented. Prevention activities need to be carried out, especially for adolescents. It is necessary to examine the relationship between internet behavior and tendencies towards violent extremism. In this study, the internet behavior that is the focus of the study is the consumption of religious material online. Several figures or studies state that the consumption of Islamic material online can encourage individuals to be extreme and violent. Therefore, this study aims to examine the dynamics of the relationship between the consumption of religious materials.

Indonesian national agency for combating terrorism (Badan Nasiona Penanggulangan Terorisme, BNPT) defines radicalism as the embryo of the birth of terrorism, namely an attitude that aims to form a total change that is revolutionary in nature by turning the existing values sharply through violence (violence) and extreme acts [25]. However, there are also those who define radicalism in a positive sense. Pius A. Partanto and M. Dahlan Al-Barry in their popular Scientific Dictionary define radicalism as a state political ideology that wants major changes to be realized as way to achieve a level of progress.

Coordinating Minister for Political, Legal and Security Affairs (Polhukam) Mahfud MD stated that there is a general and stipulative definition of radicalism. The general definition of course has positive and negative sides. While the meaning of radical stipulative is every way to dismantle the existing system in state life by means of violence. In this case, there are three types of radicals, namely takfiri, jihadi and ideological [26]. Radicalism in Indonesia today is also synonymous with anti-Pancasila or anti-state sects. Rudi Widodo (Head of the BNPT Victim Recovery Subdirectorate) said that the characteristics of radicals according to Law number 5 of 2018 are anti-Pancasila, anti-diversity, anti-NKRI and anti-Constitution 45 [27].

Schmid explained that radicalism is rooted in political movements that want and advocate for fundamental political change as a solution to existing problems and therefore also encourage changes in existing political systems and entities. The method used can be violent or not. As for extremism, they tend to use violence, command, non-dialogue, and take advantage of opportunities. According to him, the term violent extremism can describe conditions of acts of violence or terrorism that are inspired by ideological motivations or political goals [28]. This view of Schmidt is also used by Bamualim et al. in formulating the concept of the tendency of religious people to commit acts of violence or terror. They distinguish radicalism from extremism from the tendency to use violent means [21].

Stankov, Saucier, and Knežević try to approach the problem from the cognitive point of view of the actor, namely understanding the actor's point of view. According to them, there is a common or at least similar set of thoughts among perpetrators of terrorism or violence in the name of ideology. They call it the Militant Extremist Mindset (MEM). This set of thoughts becomes the basis for an individual to commit violence in the form of terrorism or other acts. The thought set includes Nastiness: War and Pro-violence, Grudge: West and Vile World, and Excuse: God, Divine Power and Utopianism [29, 30, 31]. Ozer and Bertelsen also use the same view as Stankkov et al. to develop a generally applicable definition of extremism. According to them, extremism that produces violence has two interrelated dimensions, namely support for self and group change and intolerance for groups that reject these changes [32].

From an Islamic point of view, we can use the term ghuluw. Ghuluw means excessive, a concept similar to extreme. The term ghluw means excessive in understanding or carrying out Islam so that it deviates from the original teachings [33]. There are several conditions called ghuluw, namely closing oneself and feeling that the group is the most correct (fanatic), making it difficult for oneself, bad prejudice that there is no good in others, disowning others (takfir), justifying other people's blood, understanding things from a limited point of view. partial), behave in religion without a strong argument $[34,35]$.

\section{METHODS}

This study uses a quantitative approach to the type of correlational research. Research respondents are teenagers aged 13-18 years who live in Jakarta and Yogyakarta. Respondents were obtained by offering to several youth environments in the area, namely several schools. Based on the search results, obtained 750 respondents.

To determine the condition of behavior and the tendency to recite online, the Online Recitation Behavior Scale was used. Another scale used in this study is the Extremism Scale to determine the tendency of radical and violent thinking. Both scales have been arranged in a Likert Model.

The Extremism Scale is compiled using the concepts of religious extremism mentioned above:

$$
\begin{aligned}
& \text { a. Militant Extremist Mindset (MEM) [29, 30, 31] } \\
& \text { b. Ghuluw [34, 35] } \\
& \text { c. Extremism and Pro-violence and Illegal Acts [32]. }
\end{aligned}
$$

The scale has been tested on 69 people (26 men, 43 women). After going through the item discrimination power test, it is known that there are several items that have failed so that the scale consists of 22 items. The reliability coefficient of the scale is 0.816 which indicates that the scale is able to measure steadily. 
The Online Recitation Behavior Scale is compiled from several indicators of individual behavior in deepening religion using online media. This scale was tested on 30 individuals and there was one item that needed to be dropped. The reliability coefficient of the scale is 0.662 . This shows that this scale is also able to measure individual conditions consistently.

To answer the research questions, a correlation test was conducted between the consumption of online religious materials and the tendency of violent extremism. The correlation test was carried out with the help of the SPSS program.

\section{RESULTS AND DISCUSSION}

Based on the data collected, it is known the condition of the research respondents. The description of the demographic data of research respondents can be seen in the following table.

Table 1. Description of Respondent Demographics

\begin{tabular}{|l|l|l|}
\hline Variables & Frequency & Percent \\
\hline Gender & & \\
\hline Man & 180 & $24,3 \%$ \\
\hline Woman & 561 & $75,7 \%$ \\
\hline Age & & \\
\hline$<13$ years old & 41 & $5,5 \%$ \\
\hline $13-15$ years old & 116 & $15,7 \%$ \\
\hline $15-16$ years old & 390 & $52,6 \%$ \\
\hline 17 - 18 years old & 186 & $25,1 \%$ \\
\hline$>18$ years old & 8 & $1,1 \%$ \\
\hline Domicile & & \\
\hline Yogyakarta & 334 & $45,1 \%$ \\
\hline Central Java & 99 & $13,4 \%$ \\
\hline Jakarta & 34 & $4,6 \%$ \\
\hline Banten & 274 & $37,0 \%$ \\
\hline Stage of Education/School Level & & \\
\hline Junior High School (SMP) & 150 & $20,2 \%$ \\
\hline Senior High School (SMA) & 591 & $79,8 \%$ \\
\hline Type of School & & \\
\hline Islamic Boarding school (Pesantren) & 217 & $29,28 \%$ \\
\hline Madrasa (Islamic School) & 21 & $2,83 \%$ \\
\hline Islamic Foundation's School & 335 & $45,21 \%$ \\
\hline School & 168 & $22,67 \%$ \\
\hline & & \\
\hline
\end{tabular}

Based on the table, it can be seen that the majority of respondents are female (75.7\%), aged between 15 - 16 years $(52.6 \%)$ or $17-18$ years $(25.1 \%)$, come from Yogyakarta $(45.1 \%)$ and Banten $(37.0 \%)$, currently pursuing senor high level of education $(79.8 \%)$, in schools owned by Islamic
Foundations (45.21\%). The description of the condition of the respondents' online reading behavior and extremism can be seen in the following table.

Table 2. Description of the Conditions of Respondents' Online Religious Content Consumption and Their Tendency to Extremism.

\begin{tabular}{|l|l|l|}
\hline & $\begin{array}{l}\text { Online Religious } \\
\text { Content } \\
\text { Consumption }\end{array}$ & Extremism \\
\hline Mean & 16,7935 & 62,8165 \\
\hline Std, Deviation & 4,27396 & 7,90920 \\
\hline Variance & 18,267 & 62,555 \\
\hline Range & 24,00 & 55,00 \\
\hline Minimum & 6,00 & 36,00 \\
\hline Maximum & 30,00 & 91,00 \\
\hline
\end{tabular}

Based on the table, we know that the average score of extremism accompanied by violence is quite high, namely around 62.8165 from the highest score of 91 and the lowest score of 36 . The range of scores of 55 and a standard deviation of 7.9 indicates that the scores of extremism tendencies vary. The average score for the level of online recitation behavior is also high, namely 16.7 from the highest score of 30 and the lowest 6 . The distance of the score of 24 with a standard deviation of 4.3 shows that the score of online recitation behavior is quite diverse.

We can also determine the classification of respondents' online reading behavior and respondents' tendencies to extremism using the hypothetical mean. The classification that can be used is into five classifications with the following classification criteria [36].

Table 3. Score Range Categorization of Online Religious Content Consumption and Violent Extremism.

\begin{tabular}{|c|c|c|c|}
\hline Categorization & Formula for & Online Religious & Violent \\
\hline & Score & Content & Extremism \\
\hline & Range & Consumption & Score Range \\
\hline & & Score Range & \\
\hline Very Low & $\begin{array}{c}\mathrm{X} \leq \mathrm{M}- \\
1,5 \mathrm{SD}\end{array}$ & $x \leq 11,25$ & $x \leq 31,25$ \\
\hline Low & $\begin{array}{c}\mathrm{M}-1,5 \mathrm{SD} \\
<\mathrm{X} \leq \mathrm{M}- \\
0,5 \mathrm{SD}\end{array}$ & $11,25<X \leq 15,42$ & $\begin{array}{c}31,25< \\
x \leq 48,75\end{array}$ \\
\hline Average & $\begin{array}{c}M-0,5 S D \\
<X \leq M+ \\
0,5 S D\end{array}$ & $15,42<X \leq 19,58$ & $\begin{array}{c}48,75< \\
x \leq 66,25\end{array}$ \\
\hline High & $\begin{array}{c}\mathrm{M}+0,5 \mathrm{SD} \\
<\mathrm{X} \leq \mathrm{M}+ \\
1,5 \mathrm{SD}\end{array}$ & $19,58<X \leq 23,76$ & $\begin{array}{c}66,25< \\
x \leq 83,75\end{array}$ \\
\hline
\end{tabular}




\begin{tabular}{|l|l|l|l|}
\hline Categorization & $\begin{array}{l}\text { Formula for Online Religious Violent } \\
\text { Score } \\
\text { Range }\end{array}$ & $\begin{array}{l}\text { Content } \\
\text { Consumption } \\
\text { Score Range }\end{array}$ & $\begin{array}{l}\text { Extremism } \\
\text { Score Range }\end{array}$ \\
\hline Very High & $\begin{array}{c}\mathrm{M}+1,5 \mathrm{SD} \\
<\mathrm{X}\end{array}$ & $23,76<\mathrm{X}$ & $83,75<\mathrm{X}$ \\
\hline
\end{tabular}

Based on these classification criteria, the conditions for the level of online reciting behavior and respondents' extremism were determined. It is known that the condition of online reciting behavior and respondent's extremism is as follows.

Table 4. Conditions of Respondents' Online Religious Content Consumption and Their Tendency to Extremism Categorization.

\begin{tabular}{|l|l|l|l|l|}
\hline Categorization & \multicolumn{3}{l|}{$\begin{array}{l}\text { Online } \\
\text { Content Consumption }\end{array}$} & \multicolumn{2}{l|}{ Religious } & \multicolumn{2}{l|}{} \\
\cline { 2 - 5 } & Frequency & Percent & Frequency & Percent \\
\hline Very Low & 81 & $10.9 \%$ & 0 & $0 \%$ \\
\hline Low & 189 & $25.5 \%$ & 30 & $4,0 \%$ \\
\hline Average & 278 & $37.5 \%$ & 502 & $67,7 \%$ \\
\hline High & 193 & $26.0 \%$ & 200 & $27,0 \%$ \\
\hline Very High & 0 & $0 \%$ & 9 & $1,2 \%$ \\
\hline
\end{tabular}

Before testing the correlation between Online Recitation Behavior and Extremism, it is necessary to test the prerequisites, namely the data being tested is normally distributed, linear, and free from heteroscedasticity problems.

After performing the normality test using SPSS, it was found that the data of Online Recitation Behavior $(Z=1.942$; $\mathrm{p}=0.001)$ and Extremism data $(Z=1.677 ; \mathrm{p}=0.007)$ were not normally distributed. Therefore, the statistical analysis used to test the correlation of the two variables, namely Spearman Rho, does not require the fulfillment of parametric assumptions. Based on Spearman Rho's analysis using SPSS, it was found that there was no significant correlation between online reciting behavior and extremism tendencies ( Rho = $0.017 ; \mathrm{p}=0.638)$.

In addition to the correlation test, a comparison test of the condition of online reciting behavior and the tendency of extremism between groups was also carried out based on the demographic data of the respondents owned. The respondent's data are in the form of gender, age, province of residence, school level, and type of school. Since the data did not meet the parametric assumptions, the difference test was performed using Analysis of Variation (ANOVA) which was considered more robust. Based on the ANOVA test which was conducted to compare online reading behavior and extremism in groups of gender, age, place of residence, education level, and type of school, the following results were obtained: a. There are differences in extremism based on domicile $(\mathrm{F}=21,879, \mathrm{p}=0.000)$.

b. There are differences in the tendency of extremism between groups of school types $(F=12,338 p=$ $0.000)$. The level of tendency of extremism in Islamic boarding school students (Mean $=62,502$ ) was lower than that of students in public schools managed by religious foundations (Mean $=64,451)$. The level of Islamic boarding school students' tendency to extremism was higher than that of general school students $($ Mean $=60,048)$. In addition, the level of extremism of public school students managed by religious foundations is higher than that of public school students.

The results of the correlation test show that there is no relationship between the consumption of online religious materials and the tendency of violent extremism (Rho = $0.017 ; \mathrm{p}=0.638$ ). It can be said that there is no relationship between the level of consumption of religious materials online and the level of individual extremism tendencies in adolescents. These results indicate that the consumption of religious materials online does not cause a person to become prone to violent extremism. On the other hand, individuals who have a high tendency of violent extremism do not tend to access religious materials in cyberspace.

This is in accordance with previous studies that the internet does not cause someone to become a radical, extremist, or person who tends to violent behavior. There is a direct contact fact behind it [19].

Wulandari's research on online radicalization shows the strengthening of extreme violent thinking in online radicalization. This means that women who are considered to have extreme views of violence have tended to this understanding. They then move on in cyberspace such as spreading their thoughts or supporting the thoughts of others who are in line. This condition strengthens their imagination about the concept of true Muslimah [21].

Manni's observation about the phenomena conclude that individuals who become violent extremists after accessing propaganda media are individuals who are indeed vulnerable to indoctrination process. For example, an attraction to violence or a hope to leave his old life [37]. The internet can provide space for groups that tend to be extreme and violent to share various materials needed for violent extremism activities or propaganda materials. In addition, the internet also provides a space to strengthen each other, and the opportunity to create a small community. In these small communities, ordinary individuals can be radicalized into groups [38]. The same conclusion was expressed by various other studies. Cyberspace provides space for radical extremist groups to strengthen each other among themselves. They support each other and mutually weaken material that goes against their understanding. They also use the internet as a means of strengthening their relationship [39]. 
This study found that there were differences in extreme violent tendencies based on differences in area of residence and type of school. This indicates the contribution of social and educational factors in the dynamics of strengthening violent extremism in a person. The existence of other factors in the environment that can make individuals prone to violent extremism, as well as the possibility that a person becomes more likely to become more violent extremism when interacting with propaganda materials on the internet, makes monitoring of these materials on the internet still necessary.

\section{CONCLUSION}

This study found that there was no relationship between online religious learning activities and a person's tendency to be extreme violent. However, violent and extremist material on the internet still needs to be monitored. Future research can examine the dynamics of online religious learning and extreme violent tendencies by including social factors that indicate they are related to these dynamics.

\section{ACKNOWLEDGMENTS}

The research funded by Lembaga Penelitian, Penerbitan, dan Pemberdayaan Masyarakat (LP3M) Universitas Muhammadiyah Yogyakarta (UMY). The researchers express gratitude. This condition does not affect the results for LP3M UMY has no interest in the results.

\section{REFERENCES}

[1] Biro Pusat Statistik, Berita Resmi Statistik No. 7/01/Th. XXIV, Biro Pusat Statistik, Jakarta, 2021.

[2] S. Ariteja, Demographic Bonus for Indonesia: Challenges and Policy Implications of Promoting Universal Health Coverage. Jurnal Perencanaan Pembangunan, The Indonesian Journal of Development and Planning 1 (2017) 265-274.

[3] T. Warsito. Attaining The Demographic Bonus In Indonesia, Jurnal Pajak dan Keuangan Negara 1(1) (2019) 134-139.

[4] E. T. Hendratno \& R. Fitriati, The Study of Indonesia's Readiness To Cope With Demographic Bonus: A review of Population Law, Journal of Indonesian Economy and Business 30(3) (2015) 195 - 219.

[5] Hasil Survei Penduduk 2020 Peluang Indonesia Maksimalkan Bonus Demografi. [Online]. Available: https://www.kemenkopmk.go.id/hasil-surveipenduduk-2020-peluang-indonesia-maksimalkanbonus-demografi [Accessed: Nov. 30, 2021]

[6] Sekertaris Jenderal Kementerian Tenaga Kerja Republik Indonesia (2021). Menaker Yakin Indonesia Bakal Raih Bonus Demografi dan Jadi Negara Maju. [Online]. Available: https://kemnaker.go.id/news/detail/menaker- yakin-indonesia-bakal-raih-bonus-demografi-dan-jadinegara-maju [Accessed: Nov. 30, 2021]

[7] World Health Organization, Orientation Programme On Adolescent Health for Health Care Providers. [Online]. Available: https://apps.who.int/iris/handle/10665/42868.

[Accessed: Nov. 30, 2021]

[8] Adolescent Health In The South-East Asia Region. [Online]. Available: https://www.who.int/southeastasia/healthtopics/adolescent-health [Accessed: Nov. 30, 2021]

[9] S. B. Johnson \& V. C. Jones. Adolescent Development and Risk of Injury: Using Developmental Science to Improve Interventions, Injury Prevention 17(1) (2011) $50-54$.

[10] C. Lorenz \& J. Kray. Are Mid-Adolescents Prone to Risky Decisions? The Influence of Task Setting and Individual Differences in Temperament. Frontiers Psychology. [Online]. Available: https://doi.org/10.3389/fpsyg.2019.01497 [Accessed: Nov. 30, 2021].

[11] N. Duell \& L. Steinberg. Positive Risk Taking in Adolescence. Child Development Perspective. Mar; 13(1) (2019) 48-52.

[12] A. Vannucci, E. G. Simpson, S. Gagnon, C. M. Ohannessiana. Social media use and risky behaviors in adolescents: A meta-analysis. Journal of Adolescence 79 (2020) 258-274.

[13] M. Dimock, Defining Generations: Where Millennials End and Generation Z Begins. [Online]. Available: ttps://www.pewresearch.org/facttank/2019/01/17/where-millennials-end-andgeneration-z-begins/ [Accessed: Nov. 30, 2021]

[14] J.E. White, Meet Generation Z. Grand Rapids, Michigan: Baker Publishing Group, 2017.

[15] K. Parker \& R. Igiel, On the Cusp of Adulthood and Facing an Uncertain Future: What We Know About Gen $\mathrm{Z}$ So Far. [Online]. Available: https://www.pewresearch.org/socialtrends/2020/05/14/on-the-cusp-of-adulthood-andfacing-an-uncertain-future-what-we-know-about-gen-zso-far-2/ [Accessed: Nov. 30, 2021]

[16] N. Ahmed. Generation Z's Smartphone and Social Media Usage: A Survey. Journalism and Mass Communication, 9(3), 2019, 101-122.

[17] A. Dolot, The characteristic of Generation Z, "e-mentor" (2018) 44-50

[18] Organization for Security and Co-operation in Europe (OSCE), Preventing Terrorism and Countering Violent Extremism and Radicalization that Lead to Terrorism: A 
Community-Policing Approach, OSCE \& Office for Democratic Institutions and Human Rights, Vienna, Austria, 2014, 36 \& 52.

[19] C. Winteri, P. Neumann, A. Meleagrou-Hitchens, M. Ranstorp, L. Vidino, \& J. Fürst, Online Extremism: Research Trends in Internet Activism, Radicalization, and Counter-Strategies, International Journal of Conflict and Violence 14(2) (2020) 1-20.

[20] R. R. Lubis. Potensi Pengguna Internet Indonesia Dalam Counter-Cyber Radicalization, Jurnal Pertahanan \& Bela Negara 7(2) 2017 19-34.

[21] C. S. Bamualim, H. Latief, \& I. Abubakar, Kaum Muda Muslim Milenial: Konservatisme, Hibridasi Identitas, dan Tantangan Radikalisme. Center for The Study of Religion and Culture (CSRC), Jakarta, 2018.

[22] E. Fitriana \& M. K. Ridlwan, Ngaji Online: Transformasi Ngaji Kitab Di Media Sosial, Asanka: Journal of Social Science and Education 2(2) (2021) 203-220.

[23] S. Z. Qudsy \& A. H. Muzakky, Dinamika Ngaji Online Dalam Tagar Gus Baha (\#gusbaha): Studi Living Qur'an Di Media Sosial, Poros Onim: Jurnal Sosial Keagamaan 2(1) 2021 1-19.

[24] N. Hosen, "Online Fatwa in Indonesia: From Fatwa Shopping to Googling a Kiai" in G. Fealy \& S. White (ed), Expressing Islam: Religious Life and Politics in Indonesia, 2008, 159-173

[25] Strategi Menghadapi Paham Radikalisme dan Terorisme, https://belmawa.ristekdikti.go.id, diakses pada 17 Maret 2020, pukul 16.00 WIB. [Online]. Available: https://www.who.int/southeastasia/healthtopics/adolescent-health [Accessed: Nov. 30, 2021]

[26] R. Wardi (2019). Ini Tiga Definisi Radikalisme Menurut Menko Polhukam. Beritasatu.com. diakses pada Selasa, 17 Maret 2020 pukul 13.30 WIB. [Online]. Available: https://www.who.int/southeastasia/healthtopics/adolescent-health [Accessed: Nov. 30, 2021]

[27] F. M. Sidik (2019). BNPT: Kriteria Radikal Itu AntiPancasila-NKRI-Bhinneka Tunggal Ika-UUD'45. https://news.detik.com, diakses pada Selasa 17 Maret 2020 pukul 20.28 WIB. [Online]. Available: https://www.who.int/southeastasia/healthtopics/adolescent-health [Accessed: Nov. 30, 2021]

[28] A. P. Schmid, Radicalisation, De-Radicalisation, Counter-Radicalisation: A Conceptual Discussion and Literature Review, International Centre for Counter Terrorirsm (ICCT), The Hague, 2013.

[29] L. Stankov, G. Saucier, \& G. Knežević, Militant Extremist Mindset: Proviolence, Vile World, and Divine Power. Psychological Assessment 22(1) (2010) 70-86.
[30] L. Stankov, G. Knežević, G. Saucier, B. Radović, \& B. Milovanović, Militant Extremist Mindset And The Assessment Of Radicalization In The General Population, Journal of Individual Differences, 39(2) (2018) 88-98.

[31] L. Stankov, G. Knežević, B. Petrović, J. Međedović, L. B. Lazarević, Militant Extremist Mindset in Postconflict Regions of The Balkans. Journal for Deradicalization. 19, (2019) 185-217.

[32] S. Ozer \& P. Bertelsen, Capturing Violent Radicalization: Developing And Validating Scalesmeasuring Central Aspects of Radicalization. Scandinavian Journal of Psychology, 59 (2018) 653660.

[33] S. Afroni, Makna Ghuluw Dalam Islam: Benih Ekstremisme Beragama. Wawasan: Jurnal Ilmiah Agama dan Sosial Budaya 1 (2019) 70-85.

[34] Y. Qardhawi, Al-Khashai'is Al-Ammah Li Al-Islam, Maktabah Wahbah, Kario, 1996.

[35] Y. Qardhawi, Shahwah Al-Islamiyyah Bayna AlJumud Wa Al-Tatarruf, Dar el Shorouk, Kario, 2001.

[36] S. Azwar, Penyusunan Skala Psikologi edisi 2, Pustaka Pelajar, Yogyakarta, 2012.

[37] M. Crone, Radicalization Revisited: Violence, Politics And The Skills of The Body, International Affairs 92 (3) 2016 587-604

[38] A. Meleagrou-Hitchens, \& N. Kaderbhai , Research perspectives on online radicalisation, a literature review 2006-2016, International Centre for the Study of Radicalisation, King's College London, VoxPol, London 2017.

[39] S. D. Leede, R. Haupfleisch, K. Korolkova, M. Natter, C. Carvalho, \& H. Masieh, Radicalisation and violent extremism -focus on women: How women become radicalised, and how to empower them to prevent radicalization. European Parliament, Brussels, 2017. 